\section{Modeling Actual Evapotranspiration of Viburnum odoratissimum during Production from Rooted Cuttings to Market Size Plants in 11.4-L Containers}

\author{
Richard C. Beeson, Jr. ${ }^{1}$ \\ Mid-Florida Research and Education Center, Institute of Food and \\ Agricultural Sciences, University of Florida, 2725 S. Binion Road, Apopka, \\ FL 32703
}

Additional index words. irrigation, modeling, woody shrubs, nursery production, irrigation algorithm, crop coefficient

\begin{abstract}
Rooted cuttings of Viburnum odoratissimum were grown outdoors to market size in 11.4-L containers. Actual evapotranspiration $\left(\mathbf{E T}_{\mathrm{A}}\right)$ of nine plants was determined daily as was evaporation from three control containers shaded with plastic foliage to mimic plant growth. The first $60 \mathrm{~d}$ after transplanting, substrate evaporation accounted for most of $\mathbf{E T}_{\mathrm{A}}$. Substrate evaporation was generally constant the first 160 days before declining, but still remained $\approx 160 \mathrm{~mL} /$ day through harvest at market size. $\mathbf{E T}_{\mathrm{A}}$ increased with growth and generally followed variations in reference evapotranspiration (ETo). Mean ET $_{\mathrm{A}}$ during most of the production cycle was less than $600 \mathrm{~mL} /$ day $(11.8 \mathrm{~mm}$ based on upper container surface area). With the spring growth flush, mean $\mathbf{E T}_{\mathrm{A}}$ reached $1.3 \mathrm{~L} /$ day as plants achieved market size. Mean cumulative $\mathbf{E T}_{\mathrm{A}}$ to produce $90 \%$ of measured plants to market size was $155 \mathrm{~L}$ or 3.1-m depth per plant based on container surface area. Water need indices, similar to crop coefficients, were highly correlated with percent canopy closure (\%Closure) using an exponential decay equation. When overlain with previous similar data for Ligustrum japonicum, the correlation for the combined data set had an $r^{2}=0.843$. This suggests that the \%Closure model may provide a method for ETo-based irrigation of woody shrub species based on canopy size and spacing.
\end{abstract}

Container production of woody ornamentals requires frequent and abundant irrigation. In Florida, irrigation up to $2.9 \mathrm{~m} /$ year was common in the mid-1970s in addition to an annual mean rainfall of $1.1 \mathrm{~m}$ (Harrison, 1976). In 1992, maximum allowed rates of $2.29 \mathrm{~m}$ of supplemental irrigation were imposed by Florida's Water Management Districts. In 2003, this maximum was reduced $22 \%$ for nurseries where competition for potable groundwater with expanding urban centers occurred. With further restrictions probable, it becomes imperative to know how much irrigation is required to produce container plants and to develop ways nurseries can become more precise in their irrigation applications.

In Florida, overhead irrigation of nurseries has been restricted during most of the daylight hours since the mid-1990s (Southwest Florida Water Management District, 2009). To cope with this imposition, along with decreased labor pools, irrigation at most nurseries queried occurs at night and is controlled by time clock systems (Beeson, personal communication). Most irrigation

Received for publication 7 Apr. 2010. Accepted for publication 16 June 2010.

${ }^{1}$ Associate Professor.

e-mail rcbeeson@ufl.edu. based on historical data and thus had limited usefulness.

In more recent years, modifications of the Penman-Monteith equation (Allen et al., 1998; Walter et al., 2002) have served as the basis to make daily estimates of ETo and calculations of corresponding crop coefficients $(\mathrm{Kc})$. Crop coefficients are unitless values that relate $\mathrm{ET}_{\mathrm{A}}$ to ETo and are determined empirically yet robust in application. For container-grown plants, $\mathrm{ET}_{\mathrm{A}}$ is most commonly calculated as changes in mass of the container-plant system determined by weighing. However ETo is calculated as a depth. To calculate a $\mathrm{Kc}, \mathrm{ET}_{\mathrm{A}}$ first must be converted to a depth of water by dividing by an area. Burger et al. (1987) used the container top diameter for calculating the surface area to convert $\mathrm{ET}_{\mathrm{A}}$ to a depth for 22 woody ornamental species growing in 3.8$\mathrm{L}$ containers. At market size, $\mathrm{Kc}$ ranged from 1.1 to 5.1, depending on species and container spacing. High Kc values, relative to agronomic crops that rarely exceed 1.3 (Doorenbos and Pruitt, 1977), were justified by large canopy to container surface area ratios (Burger et al., 1987). Differences in Kc values between geographically distant locations were minimum. Niu et al. (2006) used the same methodology to calculate $\mathrm{Kc}$ for five woody species in western Texas in two container sizes with different volumes but identical top diameters. Plants and containers in this study were larger than those of Burger et al. (1987). Kc values based on container top diameter ranged from 0.87 to 4.37 , similar to those reported previously for smaller plants (Burger et al., 1987; Regan, 1997). Whereas water use per unit leaf area was similar between container sizes within species, Kc values of different container sizes within species varied significantly as a result of differences in plant size. This underscores a problem with calculating $\mathrm{Kc}$ based on container top diameter; $\mathrm{Kc}$ is dependent on both container and plant size and varies with time (Beeson, 1996; Niu et al., 2006). Additionally, container top diameter varies depending on manufacturer and model. Recently Bacci et al. (2008) reported on a method to adjust Kc for plant growth by combining $\mathrm{Kc}$ as derived by Burger et al. (1987) with measurements of substrate moisture content derived from tensiometers. Kc is adjusted based on a sliding 7-d average of substrate moisture content. The system offers two concurrent, mostly independent methods of estimating daily irrigation requirements. This system relies on accurate measurements of soil matric potential, a parameter subject to measurement errors resulting from sensor placement, root growth, and especially substrate composition and time.

In 1996 Beeson (1996) reported linear relationships between ETo and $\mathrm{ET}_{\mathrm{A}}$ based on projected canopy area (PCA) and container substrate surface area. PCA was calculated by multiplying the widest canopy width by the width perpendicular to the widest width. Correlations ranged from 0.533 to 0.695 for well-irrigated treatments when $\mathrm{ET}_{\mathrm{A}}$ depth 
was based on PCA. Correlations were also significant but lower when $\mathrm{ET}_{\mathrm{A}}$ depth was based on container surface area $\left(r^{2}<0.30\right)$. The Kc's for these Ligustrum japonicum Thunb. ranged from 1.28 to 6.12 when based on container surface area, similar to those reported by others (Burger et al., 1987; Niu et al., 2006; Regan, 1997). However Kc ranged from 0.50 to 0.63 when based on PCA, which is within the range of $\mathrm{Kc}$ reported for agronomic and tree crops. For all of these studies, data collection occurred over a single growing season.

Schuch and Burger (1997) were the first to attempt modeling $\mathrm{Kc}$ for multiyear woody ornamental crops using ETo. Over a 20month production cycle, Kc ranged from 1.0 to 2.5 for woody ornamentals grown in 15.6-L containers based on container top diameter. To account for quiescent periods during winter, a Fourier curve transformation was used. In 2004, a model was presented for L. japonicum relating $\mathrm{ET}_{\mathrm{A}}$ to $\mathrm{ETo}$, plant canopy size, and spacing between containers (Beeson, 2004). The model, called the Percent Canopy Closure model, was based on daily ETo and $\mathrm{ET}_{\mathrm{A}}$ determined by weighing lysimetry for L. japonicum during a year of production from rooted cuttings to market size plants. In 2005, an algorithm derived from the model was used to control irrigation of L. japonicum from rooted cuttings to market size plants (Beeson and Brooks, 2008). The algorithm was successful in producing a crop 3 weeks earlier and with less irrigation than the manually adjusted control that was targeted for $1.8 \mathrm{~m}$ of irrigation annually.

The primary objective of the research presented here was to quantify cumulative $\mathrm{ET}_{\mathrm{A}}$ of Viburnum odoratissimum Ker Gawl (viburnum) to expand the database of woody shrub water requirements during production. The second objective was to analyze the data using the Percent Canopy Closure model and compare results with those obtained earlier with L. japonicum.

\section{Materials and Methods}

On 3 Mar. 2005, rooted cuttings of Viburnum odoratissimum produced in $5.7-\mathrm{cm}$ peat pots (70000041; Jiffy Products of American, Lorain, $\mathrm{OH})$ were transplanted into 11.4-L black polyethylene containers (C1200; Nursery Supply, Chambersburg, PA) at the MidFlorida Research and Education Center in Apopka, FL. Substrate was commercially prepared (Florida Potting Soil, Inc., Apopka, FL) and consisted of $55 \%$ pine bark fines: $36 \%$ Nupeat:9\% sand amended with $2.9 \mathrm{~kg} \cdot \mathrm{m}^{-3}$ dolomite limestone and $0.86 \mathrm{~kg} \cdot \mathrm{m}^{-3}$ micronutrients (Micro-Max; Scotts Company Inc., Marysville, $\mathrm{OH}$ ). NuPeat is a mixture of equal parts of composted hardwood bark, composted yard waste, and Florida sedge peat that passes through a $12.5-\mathrm{mm}$ screen. Containers were placed on black polyethylene ground cloth in a square arrangement within a production area measuring $9.2 \mathrm{~m} \times 9.8 \mathrm{~m}$ and irrigated at $1200 \mathrm{HR}$ as needed with overhead impact sprinklers situated at each corner. Before container placement, sprinkler heads were adjusted to achieve a Christiansen Uniformity Coefficient of 0.85 or better (Haman et al., 1977). Application rate was also calculated at that time.

Nine plants were selected and placed in suspension lysimeters for 30 -min recording of individual container-plant mass. Lysimeters consisted of $22.7-\mathrm{kg}$ load cells (SSM-AJ-50; Interface Inc., Scottsdale, AZ) suspended from 2.2-m tripods from which a basket was hung that suspended a container $\approx 25 \mathrm{~mm}$ above the ground surface. Tops of lysimeter containers were less than $4 \mathrm{~cm}$ above surrounding containers. Load cells were read using a CR10X data logger and AM416 and AM-32 multiplexers (Campbell Scientific, Inc., Logan, UT). Lysimeters were placed in the middle of three banks of plants to prevent edge effects in a completely randomized design. Each bank was five rows wide and 19 plants long. Three additional lysimeters suspending substrate-filled containers without plants were included within the production area to measure evaporation. Plastic foliage was added to these as needed to mimic canopy shading of substrate surfaces that occurred in containers of measured plants and did not interfere with substrate rehydration. Containers were spaced on 0.44-m centers at the inception of the study and not re-spaced. Daily $\mathrm{ET}_{\mathrm{A}}$ for live plants and evaporation for controls were calculated by the data logger based on changes in container-plant mass between $0600 \mathrm{HR}$ and $2200 \mathrm{HR}$. For days with rain, calculations involved manual separation of $\mathrm{ET}_{\mathrm{A}}$ from rain-induced changes in mass for each lysimeter as detailed by Beeson (2006).

Daily reference evapotranspiration (ETo) was calculated using Campbell Scientific's Application Note 4. Temperature and relative humidity were recorded using a CS-215 sensor (Campbell Scientific). Wind was measured with an anemometer (014A; Met One, Grants Pass, OR) at $2 \mathrm{~m}$ above ground level. Solar radiation was measured with a pyranometer (LI-200X; LI-COR Inc, Lincoln, NE). ETo was calculated from data collected within $50 \mathrm{~m}$ of the experimental site.

For the first 3 weeks after transplanting, all plants were irrigated with $6 \mathrm{~mm}$ of overhead irrigation daily to establish the plants. Thereafter, irrigation treatments were controlled by the lysimeter system. Irrigation of the production area was based on maximum $\mathrm{ET}_{\mathrm{A}}$ of lysimeter plants multiplied by a canopy shedding/irrigation uniformity factor set at 1.0 initially. This was increased in late summer to 1.2 to account for canopy shedding of overhead irrigation once canopies extended beyond container diameter (Beeson and Yeager, 2003). After the first 3 weeks, irrigation depths less than $6.3 \mathrm{~mm}$ were deferred to the next day and added to that day's irrigation application.

Each container was top-dressed with $55 \mathrm{~g}$ of a controlled-release fertilizer $(18 \mathrm{~N}-2.6 \mathrm{P}-$ 9.9K; 18-6-12 Polyon, 8 to 9 months; Harold's Fertilizer Inc, Clermont, FL) on 8 Mar.
2005 and was treated with pre-emergence herbicide (Ornamental Herbicide II; Scotts Co.). On 4 Apr. 2005, each container was given $\approx 150 \mathrm{~mL}$ of a $300 \mathrm{ppm}$ nitrogen liquid fertilizer (Peter's 20-20-20; Scotts Co.) solution by hand. On 23 Feb. 2006, each container received $34 \mathrm{~g}$ of $14 \mathrm{~N}-6 \mathrm{P}-11.6 \mathrm{~K}$ Osmocote (14-14-14; Scotts Co.).

Canopy measurements of widest width, width perpendicular to widest width, and average height were recorded on each lysimeter plant and four adjacent border plants generally every 3 weeks beginning shortly after transplanting. Canopy measurements were also recorded for border plants of the three control containers. The two widths were multiplied to calculate PCA for each plant. On 25 Mar. 2006, greater than $90 \%$ of measured plants had achieved market size based on Florida Grades and Standards (DACS, 1994). For this species and container size, minimum market size was an average height of $0.60 \mathrm{~m}$ and average width of $0.45 \mathrm{~m}$.

Daily $\mathrm{ET}_{\mathrm{A}}$ and evaporation were analyzed as repeated measures using GLM in SAS (Version 9.2; SAS Institute Inc., Cary, NC) with container water loss $\left(\mathrm{ET}_{\mathrm{A}}\right.$ and evaporation) as the main plot and time as the subplot (Snedecor and Cochran, 1980). $t$ tests $(P<$ $0.05)$ were used to compare between variables for each day.

The \%Closure was calculated for each lysimeter plant for each measurement date by adding the mean of half the PCA of each border plant to half the PCA of the respective lysimeter plant and then dividing by allocated bed area per plant $\left(1972 \mathrm{~cm}^{2}\right)$. Allocated bed area was essentially the square of the distance on-center between plants. With growth, canopies filled the space between containers. Because containers were not re-spaced, canopies overlapped each other as individual shoots of each plant expanded outward and up. Because \%Closure was calculated on a fixed allocated bed area, this overlap resulted in calculation of \%Closure greater than $100 \%$.

For modeling, only data for a 7-d period centered on each growth measurement date was used. Daily $\mathrm{ET}_{\mathrm{A}}\left(\mathrm{cm}^{3}\right)$ of each lysimeter plant was converted to a depth by dividing by its PCA $\left(\mathrm{cm}^{2}\right) . \mathrm{ET}_{\mathrm{A}}$ depth $(\mathrm{cm})$ was then divided by the corresponding ETo $(\mathrm{cm})$ and averaged over the $7 \mathrm{~d}$ to estimate a water needs index (WNI; Beeson and Brooks, 2008) for each lysimeter plant at each measurement date. WNI is similar to a Kc but does not meet the constraints of a large uniform fetch as defined for Kc (Doorenbos and Pruitt, 1977). The likelihood of a uniform fetch, an expansive extent of uniform vegetation of the same species, in production nurseries is rare. Hence, coefficients derived for ornamental nursery plants, by definition, cannot be called crop coefficients. WNI was coined to provide a name for coefficients derived from ornamental plant research. WNI values of the nine lysimeter replicates for each date were plotted against their respective \%Closure. The plot was fitted to a three-parameter exponential decay curve as 
reported by Beeson (2004) using SigmaPlot (Version 10; SPSS Science, Chicago, IL). Data from the viburnum were combined with similar previous data from Ligustrum japonicum and the plot fitted to the same exponential decay curve using SigmaPlot.

\section{Results and Discussion}

As was found with L. japonicum in 2001 (Beeson, 2004), for the first $56 \mathrm{~d}$ after transplanting, evaporation from substrate surfaces accounted for most of the daily water loss (Fig. 1). During this period, there were no differences between $\mathrm{ET}_{\mathrm{A}}$ and evaporation. Between then and the next $34 \mathrm{~d}, \mathrm{ET}_{\mathrm{A}}$ exceeded evaporation only $9 \mathrm{~d}$. After the first $90 \mathrm{~d}, \mathrm{ET}_{\mathrm{A}}$ exceeded evaporation of artificially shaded containers each day except for $10 \mathrm{~d}$. Eight of these were associated with rain amounts greater than $8.8 \mathrm{~mm}$. The other 2 $\mathrm{d}$ were in mid-December when ETo was less than $0.44 \mathrm{~mm}$ and rain occurred. Daily water loss ranged from 50 to $300 \mathrm{~mL}$ ( 1.0 to $6.3 \mathrm{~mm}$ based on substrate surface area) from transplanting until approximately Day 160 (90 $\mathrm{d}$ after transplanting). Low water losses from Day 98 to 108 were the result of malfunctioning irrigation solenoids. Irrigation was not supplied; thus, evaporation and transpiration were diminished these days. Viburnum transplanted in early spring would require irrigations of $6.3 \mathrm{~mm}$ or less daily for the first 3 months given similar ETo conditions (Fig. 2). This was similar to that reported for $L$. japonicum in 2001 (Beeson, 2004).

Increases in $\mathrm{ET}_{\mathrm{A}}$ began in late June (approximately Day 175) with $\mathrm{ET}_{\mathrm{A}}$ being generally $50 \%$ more than evaporation as a result of increases in shoot size represented by mean canopy width (Fig. 3). Daily ETo was generally less than 1 month previous (Fig. 2). In Florida, daily ETo peaks in May to early June at the end of the dry season. Peak ETo occurs as a result of low humidity and little cloud cover combined with solar radiation nearing its peak. Generally the wet season begins the second week of June and continues until early October. The wet season is associated with midday to afternoon cloud cover and high relative humidity that generally limits daily ETo to $5 \mathrm{~mm}$ or less.

Evaporation from artificially shaded containers was relatively constant at $200 \mathrm{~mL}$ (4 $\mathrm{mm}$ ) until early October (Day 275). At this point, mean canopy width of lysimeter plants was $33.5 \mathrm{~cm}$ with a \%Closure of $51 \%$ (Fig. 3). Thereafter, evaporation declined slowly to a baseline of $160 \mathrm{~mL}(3.1 \mathrm{~mm})$ by late November (Day 325) and remained relatively constant until plants obtained market size. During these last 5 months of near constant substrate evaporation, ETo varied between 1.2 to $4.6 \mathrm{~mm} /$ day (Fig. 2). This suggests that during this period, substrate evaporation was not coupled to the environment (Noble, 1999). In previous research with viburnum, $\mathrm{ET}_{\mathrm{A}}$ declined $40 \%$ when $\%$ Closure increased from $67 \%$ to $100 \%$ attributed principally to reductions in whole canopy transpiration caused by decoupling of lower leaves (Beeson, 2010). By

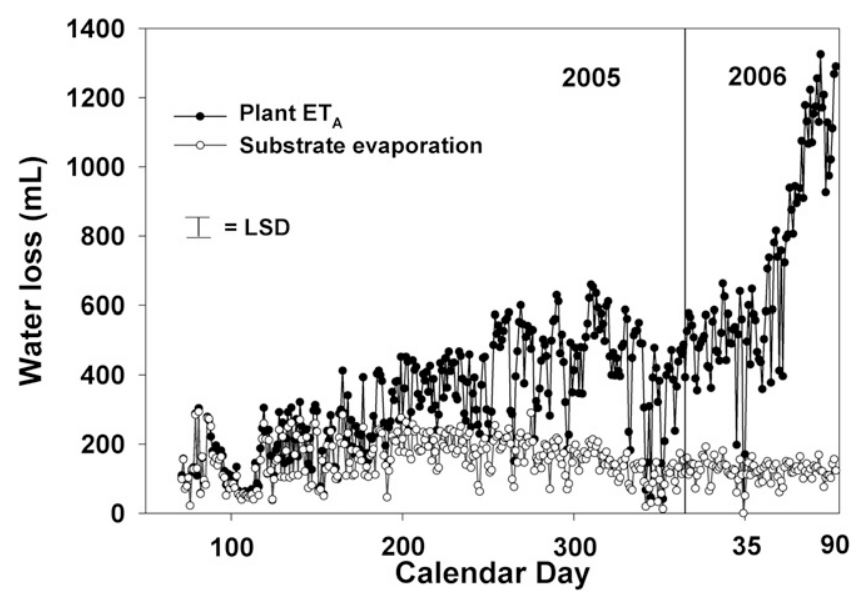

Fig. 1. Mean daily water loss through actual evapotranspiration $\left(\mathrm{ET}_{\mathrm{A}}\right)$ by Viburnum odoratissimum and evaporation from containers with artificial foliage between early Mar. 2005 and Mar. 2006. Daily ET of live plant and evaporation from control containers were calculated based on changes in mass determined from weighing lysimeters. The $\mathrm{ET}_{\mathrm{A}}$ line is representative of nine plant replicates, whereas the evaporation line is representative of three replicates. The least significant difference (LSD) line is the F-protected least significant difference between two means at $\alpha=0.05$.

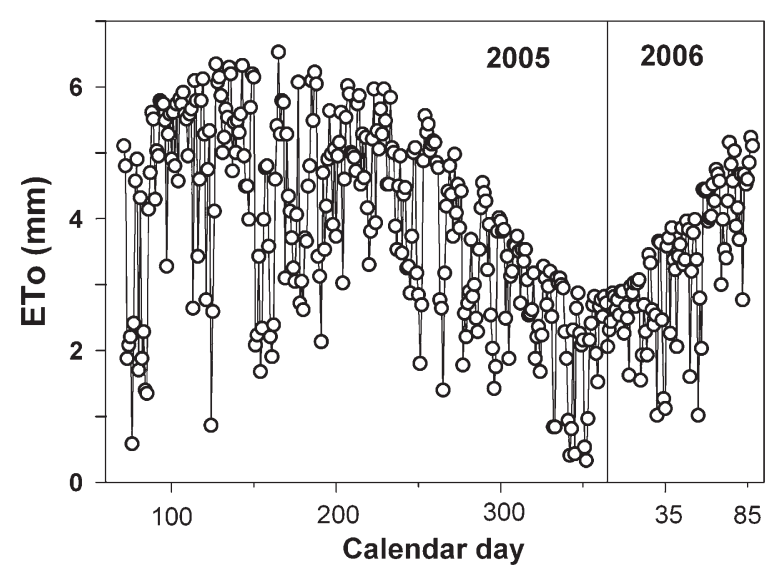

Fig. 2. Daily reference evapotranspiration (ETo) from Mar. 2005 through Mar. 2006 at the Mid-Florida Research and Education Center, Apopka, FL. during the production of Viburnum odoratissimum.

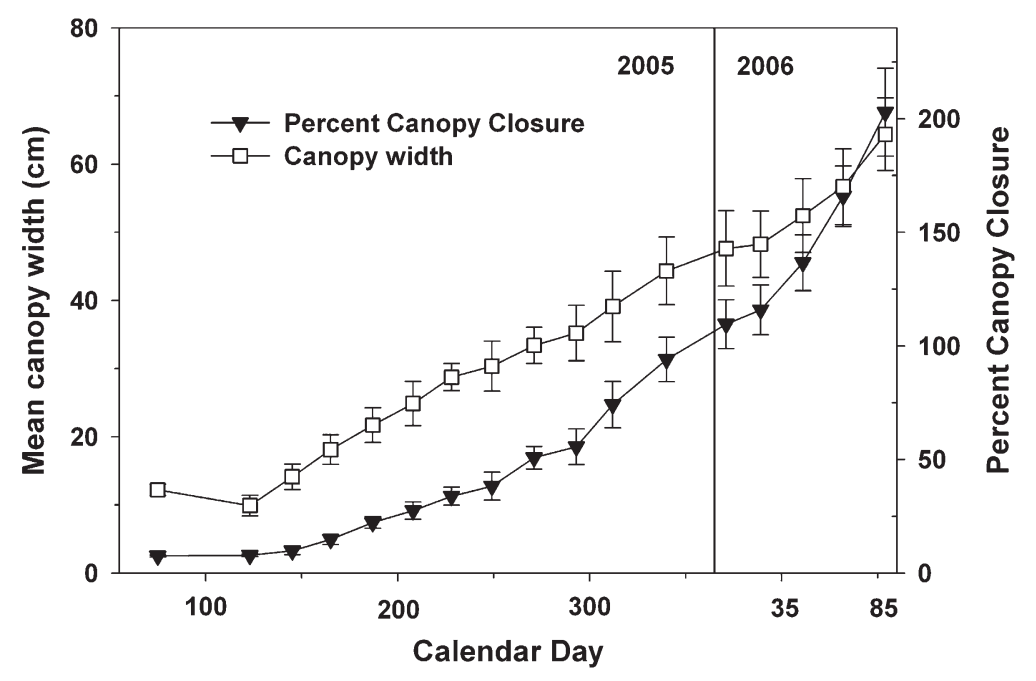

Fig. 3. Mean canopy widths measured for Viburnum odoratissimum and calculated \%Closure from canopy widths and spacing between plants during production from rooted cuttings to market size plants for 13 months beginning in early Mar. 2005. Each mean is representative of nine single plant replicates. Error bars are the SD of nine plant replicates. 
late Nov. 2005, mean \%Closure was 94\%. This level of \%Closure likely also decoupled substrate evaporation, as shown previously for $\mathrm{ET}_{\mathrm{A}}$.

Plant transpiration dipped in Dec. 2005 as a result of shorter days, lower ETo (Fig. 2), and termination of shoot growth in midDecember. $\mathrm{ET}_{\mathrm{A}}$ increased in mid-February (Fig. 1) with increasing ETo (Fig. 2) and initiation of bud break. This began a large and continuous shoot flush (Fig. 3), which doubled $\mathrm{ET}_{\mathrm{A}}$ over the course of $\approx 3$ weeks (Fig. $1)$. With this shoot flush, plants achieved market size by the end of March, $\approx 13$ months after transplanting. As plants were approaching market size, $\mathrm{ET}_{\mathrm{A}}$ was over a liter/day. In previous research (data not shown) with viburnum in the same containers with similar substrate and plant size, total plant-available water was determined to be $3.5 \mathrm{~L}$ (Beeson, 2007). Assuming similar plant-available water, at the peak in $\mathrm{ET}_{\mathrm{A}}$ at market size, $30 \%$ to $40 \%$ of plant-available water was likely lost to evapotranspiration each day.

When summed over the production period, average $\mathrm{ET}_{\mathrm{A}}$ was $155 \pm 17.8 \mathrm{~L}$ or $3.08 \pm$ $0.35 \mathrm{~m}$ in depth based on the top substrate surface area. $\mathrm{ET}_{\mathrm{A}}$ ranged from 132.4 to 192.9 $\mathrm{L}$ per plant. Rainfall during production was $1.40 \mathrm{~m}$. Although much of the rainfall supplemented overhead irrigation, rainfall in excess of container capacity was of no value. The capacity to retain rainfall would have varied day to day but would have generally increased as plants grew larger and transpired greater daily volumes of water. Nightly irrigating based on highest $\mathrm{ET}_{\mathrm{A}}$ ensured that transpiration was fully coupled to ETo for all plants. At harvest, canopy widths averaged $0.75 \mathrm{~m}$ and average height was $0.6 \mathrm{~m}$. This was wider than the three-fourths height minimum $(0.46 \mathrm{~m})$ specified in the Florida Grades and Standards (DACS, 1994) and contributed to higher cumulative $\mathrm{ET}_{\mathrm{A}}$ compared with $142.8 \pm 9.1 \mathrm{~L}(2.8 \pm 0.18 \mathrm{~m}$ depth based on top substrate surface area) that was determined for L. japonicum in 2002 (Beeson, 2004).

The plot of WNI as a function of \%Closure was fitted to an exponential decaying curve with an $r^{2}=0.868$ and $P=0.001$ (Fig. 4). This curve was based on individual plants because PCA was not uniform. Thus, the equation models individual plant WNI rather than a population WNI, which accounts for some of the variability. WNI declined rapidly with small increases in plant size with the decline slowing $\approx 20 \%$ canopy closure at experimental spacing. Similar sharp declines for young plants were previously reported for L. japonicum (Beeson, 2004). For these viburnums, this slowing of the decline in WNI would have been when an average plant canopy covered $\approx 80 \%$ of the container substrate top surface, occurring around calendar Day 180.

The rapid decline in WNI at low canopy coverage occurred with increases in canopy growth for both species. Transpiration was strongly coupled to the environment characterized by ETo, whereas substrate evaporation was not or was only weakly coupled as

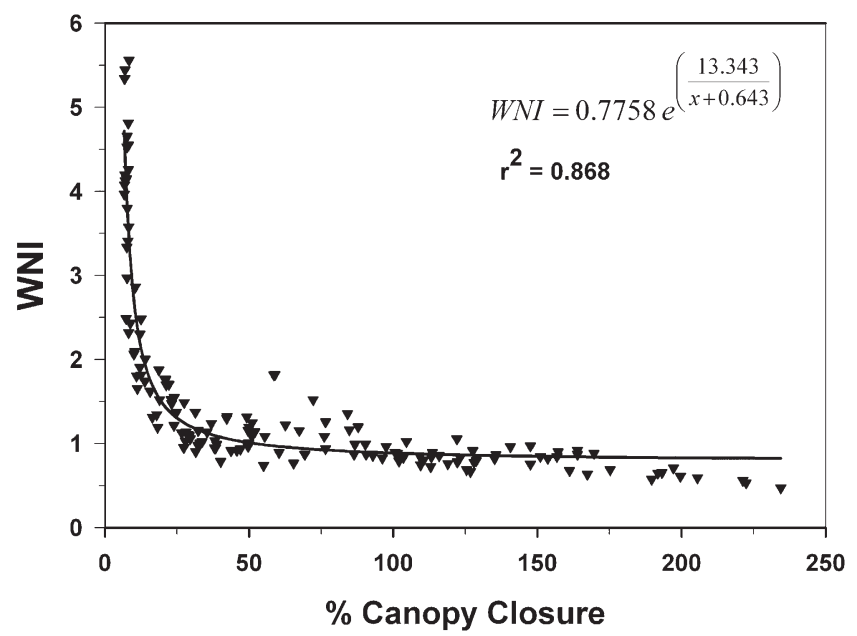

Fig. 4. Relationship between water needs index (WNI) values and corresponding \%Closure for Viburnum odoratissimum during production from rooted cuttings to market size plants in 11.4-L containers. Points are the mean of individual weeks for each of nine individual plant replicates. The equation defines the decaying exponential curve that characterizes the relationship.

evidenced by consistent surface evaporation rates (Fig. 1). For young plants, PCA was quite small, $6 \%$ to $12 \%$ of the top substrate surface area (data not shown). The contribution of transpiration to $\mathrm{ET}_{\mathrm{A}}$ was also quite small in contrast to surface evaporation. With $\mathrm{ET}_{\mathrm{A}}$ driven by evaporation, not plant transpiration, but divided by a plant's small PCA compared with the much larger substrate surface area, calculated WNI was high. With plant growth, both PCA and transpiration increased, resulting in transpiration accounting for a larger portion of $\mathrm{ET}_{\mathrm{A}}$; thus, $\mathrm{ET}_{\mathrm{A}}$ became more responsive to ETo resulting in lower WNI.

At $\approx 70 \%$ canopy closure, the rate of decline in WNI slowed as \%Closure increased. This level of canopy closure is within the range where $\mathrm{ET}_{\mathrm{A}}$ declines as a function of mutual sheltering among plants. At 100\% canopy closure, $\mathrm{ET}_{\mathrm{A}}$ was $40 \%$ lower for the same plants than at $67 \%$ closure or less (Beeson, 2010). Percent closures greater than $100 \%$ occur during production when plant canopies overlap. The greater the overlap, the denser and more uniform the overall canopy becomes, increasing overall boundary layer resistance to water vapor transfer (Noble, 1999). Increased resistance to vapor transfer lowers $\mathrm{ET}_{\mathrm{A}}$ of individual plants, seen here as declines in WNI as \%Closure increases. Nearly identical responses were observed for $L$. japonicum in the previous experiment (Beeson, 2004). For forest trees, Rose (1984) predicted this response based on shading of lower leaves and strong reductions in horizontal air movement through the lower canopy. Immediately after forests are thinned, the mirror image effect occurs as transpiration (Bréda et al., 1995) and boundary layer conductance of water vapor (Teklehaimanot et al., 1991) increase as a result of greater coupling of a tree's entire canopy to atmosphere rather than just the upper portion.

WNI calculated here and for L. japonicum is severalfold higher for young plants and proceeds in the opposite direction of $\mathrm{Kc}$ calculated for agronomic crops (Allen et al., 1998) and other woody species in containers (Burger et al., 1987; Niu et al., 2006; Regan, 1997; Schuch and Burger, 1997). Crop coefficients increase with plant growth over time as a result of increased leaf area. Here, however, WNI is plotted against \%Closure, not time. Although \%Closure is related to time, it functions differently. Percent closure was chosen for several reasons. Foremost it is a direct function of plant growth and therefore independent of plant growth rate and regional climates. When plant growth arrests resulting from dormancy or episodic cycles, WNI does not change. Plant transpiration is assumed to remain coupled to the environment characterized by ETo to the same degree with existing leaves exhibiting a consistent response. This eliminates need for Fourier curve transformations to account for changes in $\mathrm{ET}_{\mathrm{A}}$ or growth when production extends across winter dormancy as proposed by Schuch and Burger (1997). Theoretically, $\%$ Closure should also be independent of container size and spacing within limits. For evergreen plants such as viburnum or $L$. japonicum, the \%Closure model functions year-round, except when plants are exposed to sub-freezing temperature (Beeson, unpublished data). For deciduous shrubs, the \%Closure model would only be applicable when plants are nearing or in full leaf. Factors that govern $\mathrm{ET}_{\mathrm{A}}$ for evergreen plants would be similar to deciduous shrubs with a full canopy.

Data from the L. japonicum study were overlain with the viburnum results reported here to compare response of WNI to \%Closure between species and years (Fig. 5). Statistics calculated for the combined data set by SigmaPlot (SSPS) indicate the coefficients for the resulting equation were significant $(P<0.0001)$. The exponential decay equation for combined data had an $r^{2}=0.843$. This suggests that the combined equation could be used to determine WNI 


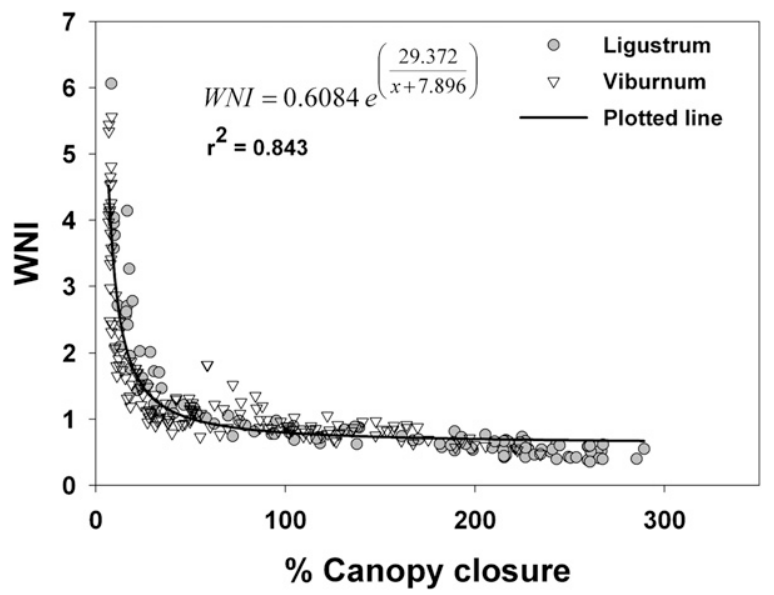

Fig. 5. Overlay of calculated water needs index (WNI) versus \%Closure for Ligustrum japonicum data collected in 2001 to 2002 and Viburnum odoratissimum data collected in 2005 to 2006. Each point represents data from nine plant replicates over 7 continuous days. The equation was derived from combined data shown.

required for estimating irrigation requirements for either species. This also suggests that the \%Closure model may be an avenue for the grouping of woody shrub species into general irrigation regimes based on canopy size and spacing.

The \%Closure model presented here offers a way to relate ETo to plant size and spacing for calculation of precise irrigation rates from simple measurements. The process is based on plant canopy responses to the environment and lends itself to automation. Once the relationship between \%Closure and WNI is established, estimation of daily $\mathrm{ET}_{\mathrm{A}}$ can be easily accomplished through spreadsheet calculations or with a computer algorithm. In practice, an irrigation manager would input container spacing likely once or twice during production, mean plant canopy width triweekly, with only ETo input daily. The greatest short-term variability in a crop's water use is directly related to the variability in solar radiation, which varies not only daily, but regionally. ETo in northwest Oregon can be $50 \%$ higher than in central Florida during the summer, mainly as a result of day length. Thus, actual $\mathrm{ET}_{\mathrm{A}}$ reported here is marginally consistent at $32^{\circ}$ latitude and a coarse estimate $800 \mathrm{~km}$ north. Models based on physiological principles are the best avenue to make limited lysimeter data available to nursery industry worldwide.

\section{Literature Cited}

Allen, R.G., L.S. Pereira, D. Raes, and M. Smith. 1998. Crop evapotranspiration: Guidelines for computing crop water requirements. FAO Irrigation and Drainage Paper 56, Rome, Italy.
Bacci, L., P. Bassista, and B. Rapi. 2008. An integrated method for irrigation scheduling of potted plants. Sci. Hort. 116:89-97.

Beeson, R.C., Jr. 1996. Penman crop coefficients for container growth landscape ornamentals, $p$. 257-262. In: Camp, C.R., E.J. Sadler, and R.E. Yoder (eds.). Proc. Intl. Conf. Evapotranspiration and Irrigation Scheduling, San Antonio, TX, 3-6 Nov.

Beeson, R.C., Jr. 2004. Modeling actual evapotranspiration of Ligustrum japonicum from rooted cuttings to commercially marketable plants in 12-liter black polyethylene containers. Acta Hort. 664:71-77.

Beeson, R.C., Jr. 2006. Relationship of plant growth and actual evapotranspiration to irrigation frequency based on managed allowable deficits for container nursery stock. J. Amer. Soc. Hort. Sci. 131:140-148.

Beeson, R.C., Jr. 2007. Determining plant available water of woody ornamentals in containers during production. HortScience 42:1700-1704

Beeson, R.C., Jr. 2010. Response of evapotranspiration of Viburnum odoratissimum to canopy closure and the implications for water conservation during production and in landscapes. HortScience 45:359-364.

Beeson R.C., Jr. and J. Brooks. 2008. Evaluation of a model based on ETo for precision irrigation using overhead sprinklers during nursery production of Ligustrum japonica grown in 11-L containers. Acta Hort. 792:85-90.

Beeson R.C., Jr. and T.H. Yeager. 2003. Plant canopy affects sprinkler application efficiency of container-grown ornamentals. HortScience 38:1373-1377.

Bréda, N., A. Granier, and G. Aussenac. 1995. Effects of thinning on soil and tree water relations, transpiration and growth in an oak forest [Quercus petraea (Matt.) Liebl.]. Tree Physiol. 15:295-306.

Burger, D.W., J.S. Hartin, D.R. Hodel, T.A. Lukaszewski, S.A. Tjosvoid, and S.A. Wagner.
1987. Water use in California's ornamental nurseries. Calif. Agr. 41:7-8.

DACS (Florida Dept. of Agriculture and Consumer Services). 1994. Grades and standards for nursery plants. Fla. Dept. of Agr. and Consumer Services, Tallahassee, FL.

Doorenbos, J. and W.O. Pruitt. 1977. Guidelines for predicting crop water requirements. Irrigation and Drainage Paper 24. 2nd Ed. Food and Agriculture Organization of the United Nations, Rome, Italy.

Fitzpatrick, G. 1980. Water budget determinations of container-grown ornamental plants. Proc. Fla. State Hort. Soc. 93:166-168.

Fitzpatrick, G. 1983a. Plant growth response to water rationing in a container nursery. HortScience 18:187-189.

Fitzpatrick, G. 1983b. Relative water demand in container-grown ornamental plants. HortScience 18:760-762.

Haman, D.Z., A.G. Smajstrla, and D.J. Pitts. 1977. Uniformity of sprinkler and microirrigation systems for nurseries. Fla. Coop. Ext. Serv. Instit. Food and Agric. Sci. Univ. Fla. Bulletin 321

Harrison, D.S. 1976. Irrigation water applied in three commercial ornamental container nurseries. Proc. Fla. State Hort. Soc. 89:311-313.

Knox, G.W. 1989. Water use and average growth index of five species of container-grown woody landscape plants. J. Environ. Hort. 7:136-139.

Niu, G., D.S. Rodriguez, R. Cabrera, C. McKenney, and W. Mackay. 2006. Determining water use and crop coefficients of five woody landscape plants. J. Environ. Hort. 24:160-165.

Nobel, P.S. 1999. Physicochemical and environmental plant physiology. 2nd Ed. Academic Press, San Diego, CA.

Regan, R. 1997. Grouping container-grown plants by water use. The Digger. 41:24-27.

Rose, C.W. 1984. Modeling evaporation: An approach to heterogeneous communities. Agr. Water Manage. 8:203-211.

Schuch, U.K. and D.G. Burger. 1997. Water use and crop coefficients of woody ornamentals in containers. J. Amer. Soc. Hort. Sci. 122:727-734.

Snedecor, G.W. and W.G. Cochran. 1980. Statistical Methods. 7th ed. The Iowa State Univ. Press, Ames, IA. 514 pp.

Southwest Florida Water Management District. 2009. Rules of the Southwest Florida Water Management District Chapter 40D-22. 40D-22.201(7).

Teklehaimanot, Z., P.G. Jarvis, and D.C. Ledger. 1991. Rainfall interception and boundary layer conductance in relation to tree spacing. J. Hydrol. (Amst.) 123:261-278.

Thornthwaite, C.W. 1948. An approach toward a rational classification of climate. Geogr. Rev. 38:55-94.

Walter, I.A., R.G. Allen, R. Elliott, D. Itenfisu, P. Brown, M.E. Jensen, B. Mecham, T.A. Howell, R.L. Snyder, S. Eching, T. Spofford, M. Hattendorf, D. Martin, R.H. Cuenca, and J.L. Wright. 2002. The ASCE standardized reference evapotranspiration equation. Rep. Task Com. on Standardized Reference Evapotranspiration, 9 July 2002, EWRI-Am. Soc. Civil. Engr., Reston, VA. 26 May 2010. <http:// www.kimberly.uidaho.edu/water/asceewri/main. pdf $>$. 